\title{
Acceptability and Preferences among Men and Women for Male Involvement in Antenatal Care
}

\author{
Nompumelelo Yende, ${ }^{1}$ Annelies Van Rie, ${ }^{2}$ Nora S. West, ${ }^{1}$ \\ Jean Bassett, ${ }^{1}$ and Sheree R. Schwartz ${ }^{3}$ \\ ${ }^{1}$ Witkoppen Health and Welfare Centre, Johannesburg, South Africa \\ ${ }^{2}$ Department of Epidemiology, University of North Carolina Gillings School of Global Health, Chapel Hill, NC, USA \\ ${ }^{3}$ Department of Epidemiology, Johns Hopkins Bloomberg School of Public Health, Baltimore, MD, USA
}

Correspondence should be addressed to Sheree R. Schwartz; sschwartz@jhu.edu

Received 23 June 2016; Accepted 25 December 2016; Published 24 January 2017

Academic Editor: Keith A. Eddleman

Copyright ( 2017 Nompumelelo Yende et al. This is an open access article distributed under the Creative Commons Attribution License, which permits unrestricted use, distribution, and reproduction in any medium, provided the original work is properly cited.

\begin{abstract}
Introduction. Male involvement in antenatal care (ANC) has been associated with improved prevention of mother-to-child transmission outcomes in Sub-Saharan Africa; yet it remains uncommon. We assess acceptability of male involvement from the male and female perspectives and potential incentives for men to attend ANC. Methods. Adult pregnant women and men attending primary healthcare at Witkoppen Health and Welfare Centre in Johannesburg, South Africa, from October 2013 to January 2014, were recruited using stratified random sampling to ensure equal representation across gender and HIV status. Results. $300 / 332$ individuals (93.8\%) offered participation consented. Among the 150 women, 97\% had a partner; the majority (92\%) preferred partner attendance at ANC, and 14\% reported partner attendance during this pregnancy. The 150 men had low knowledge of services rendered at ANC outside of pregnancy monitoring, and few (19\%) had previously attended ANC. Blood pressure screening, fatherhood information, and HIV testing were identified by men as incentives for attendance. Women and men expressed high willingness to, respectively, deliver (95\%) and respond (97\%) to ANC letter invitations. Conclusion. Invitation letters to promote male involvement in ANC are highly acceptable to pregnant women and men. Focusing invitation messages on fatherhood and primary healthcare rather than HIV testing may provide greater motivation for male involvement.
\end{abstract}

\section{Introduction}

Improved engagement in antenatal care (ANC) and prevention of mother-to-child transmission (PMTCT) programmes during pregnancy have resulted in substantial reductions in mother-to-child transmission of HIV in South Africa, but loss to follow-up from antiretroviral therapy (ART) programmes is prominent, especially in the postpartum period and among women newly diagnosed with HIV during pregnancy $[1,2]$. One contributing factor may be that women who have not disclosed their HIV status to a partner or family members can no longer attribute to pregnancy regular clinic visits and daily medication intake during the postpartum period [3]. Interventions to retain women in ART care during pregnancy and postpartum are thus needed to ensure optimal health outcomes for the mother and child $[4,5]$.
Because men have social and economic roles within families that can influence decisions related to the health of the mother and child, participation of men in ANC and family health is one potential solution to improve PMTCT outcomes [6-8]. A study in Kenya found that male involvement was associated with increased adherence to maternal ART prophylaxis, better adherence to infant feeding methods, and a $45 \%$ decrease in risk of HIV transmission from mothers to infants over a one-year period [6]. Testing couples in ANC may provide a mechanism through which HIV-infected women can disclose and/or receive treatment support from their partners. Similarly, when the female partner tests negative, couples testing can help to identify risks for acute infection during pregnancy.

Several barriers result in poor ANC attendance by male partners $[9,10]$. Throughout much of the world maternal 
and infant health are perceived as women's responsibilities and men often do not feel welcome at ANC as no other men are in ANC waiting rooms, negative healthcare provider treatment of male partners, and long wait times [9, 1114]. In addition, men may have employment responsibilities resulting in opportunity-costs of lost wages.

Invitation letters have been suggested as one potential approach to increase male involvement [10], but few data are available on the acceptability to men and women of such letters and their effect on HIV testing or retention in care [15]. To inform the design of a male involvement intervention, we assessed the acceptability of male involvement in PMTCT and the willingness of women and men to distribute and respond to a letter invitation, as well as preferences for specific elements of a male involvement invitation letter.

\section{Methods}

2.1. Study Design and Population. Participants were enrolled in a cross-sectional study at Witkoppen Health and Welfare Centre (Witkoppen), a primary health clinic in Johannesburg, South Africa, between October 2013 and January 2014. Every third man aged 18-59 years receiving care at the HIV clinic and every fifth man receiving general non-HIV care for issues other than acute illnesses were screened for eligibility and invited to participate if eligible. Every third pregnant woman aged $\geq 18$ years known to be HIV positive at enrolment and every fifth HIV negative pregnant woman were eligible to participate if they were attending the antenatal clinic. A stratified sampling strategy was used to ensure that an equal number of men and women ( $n=150$ each), as well as equal numbers of people living with and without HIV ( $n=150$ each), were included.

Trained research assistants administered a one-time, anonymous, structured questionnaire in English, isiZulu, or SeSotho to collect data on demographics, reproductive and HIV-related history, and knowledge, acceptability, and preferences related to male participation in ANC. Participants were also asked to review two invitation letters and indicate which letter they preferred and to assess specific passages of the letters (see Appendix for Supplementary Materials available online at https://doi.org/10.1155/2017/4758017). Passages related to reasons for attending ANC and activities that would be undertaken at ANC. Reading comprehension was assessed for all participants and letters were read aloud to participants in cases of poor comprehension.

2.2. Ethics, Consents, and Permissions. This study was approved by the Human Research Ethics Committee at the University of the Witwatersrand in Johannesburg, South Africa, and the Institutional Review Board at the University of North Carolina at Chapel Hill in the United States. All participants provided written informed consent.

2.3. Statistical Analyses. Differences in the distribution of characteristics between groups were compared using Fisher's exact tests and Wilcoxon rank sum tests. The study had $80 \%$ power to detect a $>1.5$-fold difference in acceptability of male involvement between men and women, assuming at least $40 \%$ of all participants found male involvement to be acceptable. All analyses were conducted in Stata 12.1 (College Station, TX, USA).

\section{Results}

Of the 332 individuals invited, 300 (90.4\%) agreed to participate. Reasons for attending Witkoppen clinic among the 150 men enrolled were not feeling well $(n=58,38.7 \%)$, HIV treatment $(n=53,35.3 \%)$, routine checkup $(n=28,18.7 \%)$, HIV testing ( $n=7,4.7 \%)$, or other $(n=4,2.6 \%)$. Among the 150 pregnant women receiving ANC, the median gestational age was 24 weeks (interquartile range [IQR] 17-31).

Participating men were older, were more likely to be employed, had higher incomes, had attained a lower education level, and had more children than participating women (Table 1). By design, 50\% of all men and women were HIV positive; more men than women were unaware of their HIV status $(16.7 \%$ versus $6.0 \%, p<0.01)$. Women were more likely than men to be in a relationship $(97.3 \%$ versus $87.3 \%$, $p<0.01$ ) with an average 6-year duration of the relationship ( 5 years for women, 7 years for men, $p<0.01$ ). The majority of participants $(81.6 \%)$ had disclosed their status to their partner, with similar proportion of men and women having disclosed to their partners.

3.1. Experience with Male Involvement. Few $(n=21 / 146$, $14 \%)$ women with a current partner reported that their male partner had attended an ANC visit with them during the current pregnancy, and 20\% $(n=29 / 147)$ of men reported prior ANC attendance with a partner (Table 1). Characteristics of men who had and had not attended ANC were similar except for a higher level of education among men who had ever attended an ANC visit (Table 2). Among HIV positive men, $100 \%$ of those who had attended ANC had disclosed their HIV status to their recent partner compared to $82 \%$ disclosure rate among those who have never attended an ANC visit, though the difference was not statistically significant $(p=0.19)$.

Even though two-thirds of women $(n=96 / 143,65.0 \%$, data missing for 3 women with partners) had invited their male partner to accompany them to an ANC visit, only 21 (14.4\%) women reported that their male partner had actually accompanied them during their current pregnancy. Women who had or had not invited a partner to attend ANC were similar, with the exception that fewer women who received their HIV diagnosis during pregnancy had invited a male partner to an ANC visit (45.8\% versus $14.3 \%, p<0.01$, Table 2).

3.2. Knowledge, Acceptability, and Preferences for Male Involvement in ANC. The majority of men knew that monitoring the baby's progress $(76 \%)$ and maternal HIV testing (63\%) are part of ANC services (Figure 1). Other ANC activities, such as breastfeeding and nutrition counselling, STI screening, and blood pressure screening, were known by less than $20 \%$ of men. Both men and women believed that services for fathers as part of ANC could encourage them to attend. Almost all men ( $\geq 90 \%)$ were interested in fatherhood 
TABLE 1: Characteristics of men and women interviewed about acceptability of male involvement in antenatal care.

\begin{tabular}{|c|c|c|c|c|}
\hline Characteristics & Overall $(n=300)$ & $\begin{array}{c}\text { Men } \\
(n=150)\end{array}$ & Women $(n=150)$ & $p$ value \\
\hline \multicolumn{5}{|l|}{ Age in years, $n(\%)$} \\
\hline $18-24$ & $52(17.3)$ & $9(6.0)$ & $43(28.7)$ & \multirow{3}{*}{$<0.01$} \\
\hline $25-34$ & $132(44.0)$ & $49(32.7)$ & $83(55.3)$ & \\
\hline 35 and over & $116(38.7)$ & $92(61.3)$ & $24(16.0)$ & \\
\hline Employment, $n(\%)$ & $166(55.3)$ & $107(71.3)$ & $59(39.3)$ & $<0.01$ \\
\hline $\begin{array}{l}\text { Median monthly income, } \\
\text { USD [IQR] }\end{array}$ & 294 [245-392] & $343[245-441]$ & 275 [216-343] & $<0.01$ \\
\hline \multicolumn{5}{|l|}{ Education, $n(\%)$} \\
\hline None & $4(1.3)$ & $4(2.7)$ & $0(0.0)$ & \multirow{4}{*}{$<0.01$} \\
\hline Primary school & $72(24.0)$ & $52(34.7)$ & $20(13.3)$ & \\
\hline Secondary school & $132(44.0)$ & $63(42.0)$ & $69(46.0)$ & \\
\hline $\begin{array}{l}\text { Matriculated } \\
\text { secondary/tertiary }\end{array}$ & $02(30.7)$ & $31(20.6)$ & $61(40.7)$ & \\
\hline \multicolumn{5}{|l|}{ Country of origin, $n(\%)$} \\
\hline South Africa & $171(57.0)$ & $81(54.0)$ & $90(60.0)$ & \multirow{3}{*}{0.10} \\
\hline Zimbabwe & $86(28.7)$ & $41(27.3)$ & $45(30.0)$ & \\
\hline Other & $43(14.3)$ & $28(18.7)$ & $15(10.0)$ & \\
\hline \multicolumn{5}{|l|}{$\begin{array}{l}\text { Number of living children, } \\
n(\%)\end{array}$} \\
\hline None & $53(17.7)$ & $15(10.0)$ & $38(25.3)$ & \multirow{3}{*}{$<0.01$} \\
\hline One & $98(32.7)$ & $36(24.0)$ & $62(41.3)$ & \\
\hline Two or more & $149(49.6)$ & $99(66.0)$ & $50(33.4)$ & \\
\hline \multicolumn{5}{|l|}{ HIV status, $n(\%)$} \\
\hline HIV positive & $150(50.0)$ & $75(50.0)$ & $75(50.0)$ & \multirow{3}{*}{$<0.01$} \\
\hline HIV negative & $16(38.7)$ & $50(33.3)$ & $66(44.0)$ & \\
\hline Unknown & $34(11.3)$ & $25(16.7)$ & $9(6.0)$ & \\
\hline $\begin{array}{l}\text { Currently in a relationship, } \\
n(\%)\end{array}$ & $277(92.3)$ & $131(87.3)$ & $146(97.3)$ & $<0.01$ \\
\hline $\begin{array}{l}\text { Median age of partner, } \\
\text { years }[\mathrm{IQR}]^{\dagger, \neq}\end{array}$ & $32[28-37]$ & $32[26-37]$ & $32[28-36]$ & 0.84 \\
\hline $\begin{array}{l}\text { Mean years in relationship } \\
\text { with main partner, }[\mathrm{IQR}]^{\dagger}\end{array}$ & $6[3-11]$ & $7[5-15]$ & $5[2-8]$ & $<0.01$ \\
\hline $\begin{array}{l}\text { Male partner attended } \\
\text { antenatal care during } \\
\text { current pregnancy, } n(\%)\end{array}$ & - & - & $21(14.4)$ & - \\
\hline $\begin{array}{l}\text { Attended antenatal care } \\
\text { with a female partner in the } \\
\text { past, } n(\%)^{\S}\end{array}$ & - & $29(19.7)$ & - & - \\
\hline $\begin{array}{l}\text { Disclosed HIV status to } \\
\text { most recent partner, } n \\
(\%)^{\S, 9}\end{array}$ & $120(81.6)$ & $62(84.9)$ & $58(78.4)$ & 0.40 \\
\hline $\begin{array}{l}\text { Want male partners to } \\
\text { attend/perceive that female } \\
\text { partners would want them } \\
\text { to attend } \|, * *\end{array}$ & $275(93.5 \%)$ & $142(95.3 \%)$ & $133(91.7)$ & 0.24 \\
\hline \multicolumn{5}{|l|}{$\begin{array}{l}\text { Willing to } \\
\text { distribute/respond to ANC } \\
\text { invitation letter, } n(\%)^{\dagger \dagger}\end{array}$} \\
\hline Yes & 283 (95.9) & 145 (96.6) & $138(95.2)$ & \multirow{3}{*}{0.01} \\
\hline No & $8(2.7)$ & $1(0.7)$ & $7(4.8)$ & \\
\hline Not sure & $4(1.4)$ & $4(2.7)$ & $0(0.0)$ & \\
\hline
\end{tabular}


TABLE 2: Characteristics of men's attendance and women's invitation of men to antenatal care $(n=294)$.

\begin{tabular}{|c|c|c|c|c|c|c|}
\hline \multirow[b]{2}{*}{ Characteristics } & \multicolumn{3}{|c|}{$\operatorname{Men}(n=147)$} & \multicolumn{3}{|c|}{ Women $(n=147)$} \\
\hline & $\begin{array}{c}\text { History of } \\
\text { attending } \\
\text { ANC }(n=29)\end{array}$ & $\begin{array}{l}\text { Never attended } \\
\text { ANC }(n=118)\end{array}$ & $p$ value & $\begin{array}{c}\text { Women who } \\
\text { invited partner to } \\
\text { ANC } \\
(n=96)\end{array}$ & $\begin{array}{l}\text { Women who had } \\
\text { not invited partner } \\
\text { to ANC }(n=51)\end{array}$ & $p$ value \\
\hline \multicolumn{7}{|l|}{ Age in years, $n(\%)$} \\
\hline $18-24$ & $3(10.3)$ & $6(5.1)$ & \multirow{3}{*}{0.45} & $23(24.0)$ & $19(37.3)$ & \multirow{3}{*}{0.16} \\
\hline $25-34$ & $10(34.5)$ & $36(30.5)$ & & $58(60.4)$ & $23(45.1)$ & \\
\hline 35 and over & $16(55.2)$ & $76(64.4)$ & & $15(15.6)$ & $9(17.6)$ & \\
\hline \multicolumn{7}{|l|}{ Education, $n(\%)$} \\
\hline None/primary & $12(41.4)$ & $43(36.4)$ & \multirow{3}{*}{0.03} & $16(16.7)$ & $4(7.8)$ & \multirow{3}{*}{0.10} \\
\hline Secondary & $7(24.1)$ & $56(47.5)$ & & $38(39.6)$ & $29(56.9)$ & \\
\hline $\begin{array}{l}\text { Matriculated } \\
\text { secondary/tertiary }\end{array}$ & $10(34.5)$ & $19(16.1)$ & & $42(43.7)$ & $18(35.3)$ & \\
\hline \multicolumn{7}{|l|}{ Country of origin, $n(\%)$} \\
\hline South Africa & $16(55.2)$ & $63(53.4)$ & \multirow{3}{*}{0.52} & $56(58.3)$ & $32(62.7)$ & \multirow{3}{*}{0.50} \\
\hline Zimbabwe & $6(20.7)$ & 35 (29.7) & & $28(29.2)$ & $16(31.4)$ & \\
\hline Other & $7(24.1)$ & $20(16.9)$ & & $12(12.5)$ & $3(5.9)$ & \\
\hline \multicolumn{7}{|l|}{$\begin{array}{l}\text { Number of living children, } \\
n(\%)^{*}\end{array}$} \\
\hline None & - & - & \multirow{3}{*}{0.48} & $24(25.0)$ & $13(25.5)$ & \multirow{3}{*}{0.82} \\
\hline One & $6(20.7)$ & $29(28.2)$ & & $39(40.6)$ & $23(45.1)$ & \\
\hline Two or more & $23(79.3)$ & $74(71.8)$ & & $33(34.4)$ & $15(29.4)$ & \\
\hline \multicolumn{7}{|l|}{$\begin{array}{l}\text { Talk to partner about HIV, } \\
n(\%)^{\dagger, \ddagger}\end{array}$} \\
\hline Yes & $26(92.0)$ & $89(89.0)$ & \multirow{2}{*}{0.73} & $87(93.5)$ & $38(84.4)$ & \multirow{2}{*}{0.12} \\
\hline No & $2(7.1)$ & $11(11.0)$ & & $6(6.5)$ & $7(15.6)$ & \\
\hline \multicolumn{7}{|l|}{ HIV status, $n(\%)$} \\
\hline HIV positive & $12(41.4)$ & $63(53.4)$ & \multirow{2}{*}{0.30} & $50(52.1)$ & $24(47.1)$ & \multirow{2}{*}{0.61} \\
\hline HIV negative/unknown & $17(58.6)$ & $55(46.6)$ & & $46(47.9)$ & $27(52.9)$ & \\
\hline \multicolumn{7}{|l|}{$\begin{array}{l}\text { Disclosed HIV status to } \\
\text { most recent partner, } n \\
(\%)^{\S, 9}\end{array}$} \\
\hline Yes & $12(100.0)$ & $50(82.0)$ & \multirow{2}{*}{0.19} & $41(83.7)$ & $16(66.7)$ & \multirow{2}{*}{0.13} \\
\hline No & $0(0.0)$ & $11(18.0)$ & & $8(16.3)$ & $8(33.3)$ & \\
\hline \multicolumn{7}{|l|}{$\begin{array}{l}\text { Relationship duration with } \\
\text { partner, } n(\%)^{\dagger}\end{array}$} \\
\hline$<2$ years & $1(3.6)$ & $8(8.0)$ & \multirow{2}{*}{0.68} & $15(15.6)$ & $10(21.3)$ & 0.48 \\
\hline$\geq 2$ years & $27(96.4)$ & $92(92.0)$ & & $81(84.4)$ & $37(78.7)$ & \\
\hline $\begin{array}{l}\text { Pregnant at time of HIV } \\
\text { diagnosis }^{\|, * *}\end{array}$ & - & - & - & & & \\
\hline Yes & - & - & - & - & $13(54.2)$ & $<0.01$ \\
\hline No & - & - & - & - & $11(45.8)$ & \\
\hline $\begin{array}{l}\text { Level of financial support } \\
\text { from partner } r^{\dagger, * *}\end{array}$ & - & - & - & & & \\
\hline None/some & - & - & - & $34(36.2)$ & $21(44.7)$ & 0.36 \\
\hline A lot of support & - & - & - & $60(63.8)$ & $26(55.3)$ & \\
\hline $\begin{array}{l}\text { Level of emotional support } \\
\text { from partner }{ }^{\dagger, \dagger \dagger}\end{array}$ & - & - & - & & & \\
\hline None/some & - & - & - & $42(45.2)$ & $23(48.9)$ & 0.72 \\
\hline A lot of support & - & - & - & $51(54.8)$ & $24(51.1)$ & \\
\hline
\end{tabular}




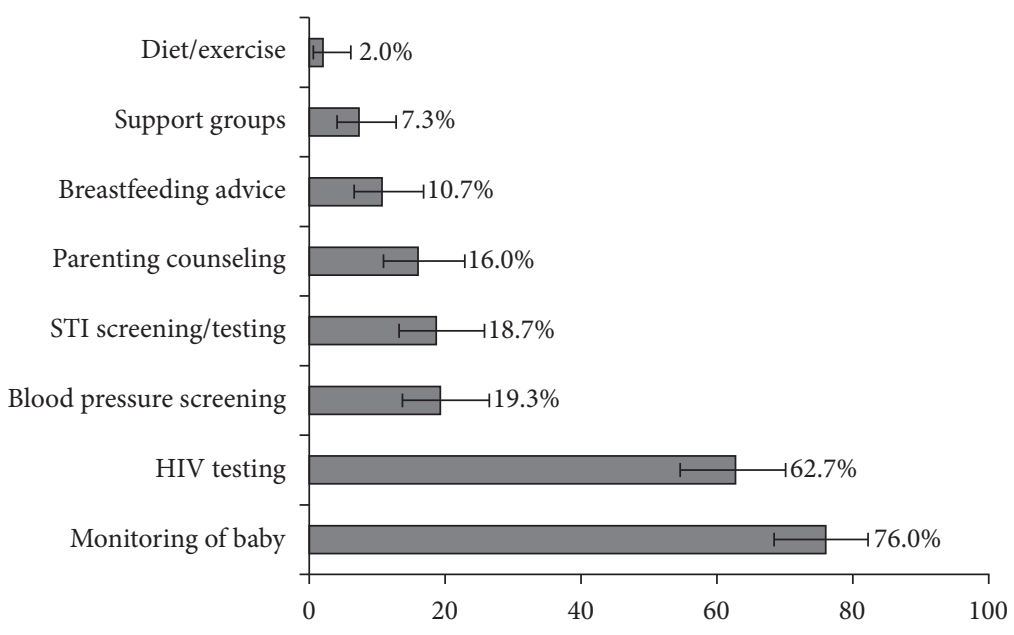

(\%)

Figure 1: Men's knowledge of services provided to women at antenatal care.

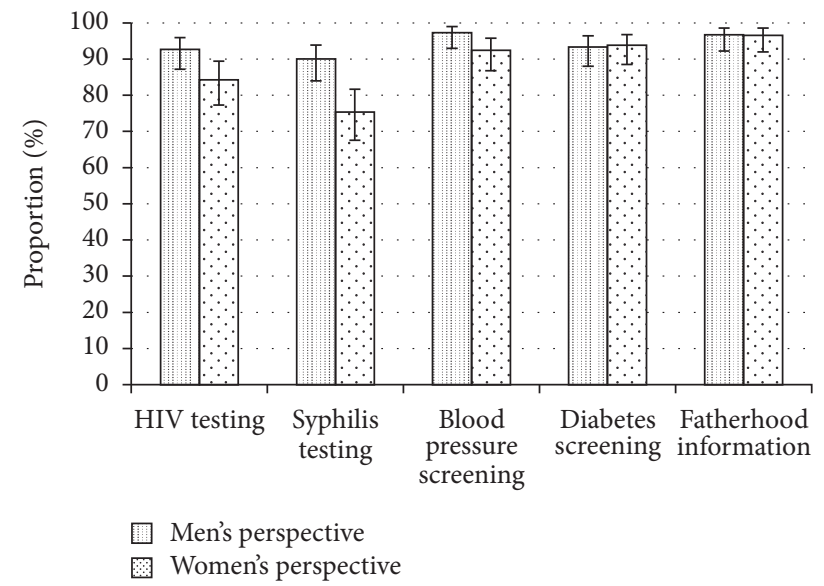

FIGURE 2: Incentives for male attendance at antenatal care. Men's and women's perspectives of what healthcare services could be provided to men at the antenatal clinic as an incentive to come to the clinic with their partners.

information, HIV testing, and screening for blood pressure, syphilis, and diabetes (Figure 2). Women were less likely than men to report HIV and syphilis testing as incentives for male involvement in ANC (Figure 2, $p=0.03$ and $p<0.01$, resp.).

Almost all (92\%, $n=133 / 145$ women in relationships, missing for $n=1$ ) women reported they would like their partners to attend their ANC visit and 95\% (138/145) would give their partners letter invitations. Among HIV negative women and HIV positive women who had not yet disclosed their status to their partner $(n=87), 95 \%$ preferred couples testing in ANC to individual HIV testing. Most men (95\%, $n=142 / 149$, missing for $n=1$ ) believed that their partners would want them to attend ANC if given the option and almost all $(97 \%, 145 / 150)$ men said they would attend an ANC visit if they received a letter invitation from their partners. Among the few $(2.7 \%, 8 / 150)$ individuals not willing to participate in an ANC invitation programme, almost all (7/8) were women, of which 3 were HIV positive and 4 were HIV negative.

Men identified time off from work as their greatest barrier to attending ANC with a partner (38\%), followed by no other men at the clinic (14\%), transport cost (13\%), and long wait times (10\%). Less than five percent of men listed cultural/religious beliefs, partners' preferences, or clinic hours as the main barrier to attending ANC. Twenty percent of men reported no barrier to attending ANC. Men preferred Saturdays and early weekday mornings as optimal attendance hours. Most men (96\%) were in favour of a "Father's Day" at the clinic in which men would attend ANC on the same day and multiple activities for fathers-to-be would be offered on those days.

Men and women read over sample ANC male invitation letters (see online supplement). While $70 \%$ of women expressed a preference for one of the two letters, men were almost split equally (46 versus $54 \%$ ) in their preference for the letters. The majority of men (55\%) preferred positive messages related to fatherhood and being a supportive partner rather than an emphasis on prior research findings suggesting improved maternal and child health outcomes from male involvement; most women (65\%) preferred the latter (Table 3). Both men (53\%) and women (68\%) preferred a more general description of counselling and health assessments offered to men at ANC rather than a focus on testing for HIV and sexually transmitted infections. No differences were observed by HIV status of the participant (results not shown).

\section{Discussion}

We found a high willingness among both women and men, independent of HIV status, to embrace male involvement in ANC. These findings echo those from a study in Cameroon indicating high acceptability among women for male involvement in ANC [16]. Despite high acceptability, only $14 \%$ of 
TABLE 3: Preferences among men and women for different components of male ANC invitation letters.

\begin{tabular}{|c|c|c|c|c|c|}
\hline Letter parts & $\begin{array}{l}\text { Text from Letter } \\
\text { "A" }\end{array}$ & $\begin{array}{l}\text { Text from Letter } \\
\text { "B" }\end{array}$ & $\begin{array}{c}\text { Male } \\
\text { preferences }\end{array}$ & Female preferences & $\begin{array}{l}p \text { value assessing } \\
\text { difference in } \\
\text { preferences }\end{array}$ \\
\hline $\begin{array}{l}\text { Why to come to } \\
\text { ANC? }\end{array}$ & $\begin{array}{l}\text { Why should you } \\
\text { come for the visit? } \\
\text { Your child's health } \\
\text { also depends on } \\
\text { you, even before } \\
\text { your child has been } \\
\text { born. A good } \\
\text { father supports his } \\
\text { partner in } \\
\text { attending ANC } \\
\text { and getting tested } \\
\text { along with her. }\end{array}$ & $\begin{array}{l}\text { Why should you } \\
\text { come for the visit? } \\
\text { Research shows } \\
\text { that when fathers } \\
\text { attend antenatal } \\
\text { care with their } \\
\text { partners, both } \\
\text { mothers and babies } \\
\text { have better health } \\
\text { outcomes. Your } \\
\text { child's health also } \\
\text { depends on you, } \\
\text { even before your } \\
\text { child has been } \\
\text { born. }\end{array}$ & $\begin{array}{l}55 \% \text { of men prefer } \\
\text { wording in } \\
\text { Letter } A\end{array}$ & $\begin{array}{l}65 \% \text { of women } \\
\text { prefer wording in } \\
\text { Letter } B\end{array}$ & $<0.01$ \\
\hline $\begin{array}{l}\text { What will happen } \\
\text { at ANC? }\end{array}$ & $\begin{array}{l}\text { What will happen } \\
\text { during the visit? } \\
\text { We will provide } \\
\text { special counselling } \\
\text { for fathers who are } \\
\text { expecting a baby so } \\
\text { that you know how } \\
\text { to support your } \\
\text { partner and your } \\
\text { new baby. } \\
\text { You will be offered } \\
\text { testing for HIV and } \\
\text { also other Sexually } \\
\text { Transmitted } \\
\text { Infections (STI) } \\
\text { You will receive } \\
\text { counselling on how } \\
\text { to keep yourself } \\
\text { and your child } \\
\text { healthy and } \\
\text { prevent your child } \\
\text { from getting HIV. }\end{array}$ & $\begin{array}{l}\text { What will happen } \\
\text { during the visit? } \\
\text { You will } \\
\text { accompany your } \\
\text { partner and learn } \\
\text { about your baby. } \\
\text { We will provide } \\
\text { special counselling } \\
\text { for fathers who are } \\
\text { expecting a baby so } \\
\text { that you know how } \\
\text { to support your } \\
\text { partner and your } \\
\text { new baby. } \\
\text { Your health affects } \\
\text { your ability to be a } \\
\text { good parent. Thus, } \\
\text { along with making } \\
\text { sure that your } \\
\text { partner and child } \\
\text { are healthy, we will } \\
\text { offer you a basic } \\
\text { health assessment, } \\
\text { including blood } \\
\text { pressure reading } \\
\text { and screening for } \\
\text { infections that can } \\
\text { be treated. }\end{array}$ & $\begin{array}{l}53 \% \text { of men prefer } \\
\text { wording in } \\
\text { Letter } B\end{array}$ & $\begin{array}{l}68 \% \text { of women } \\
\text { prefer wording in } \\
\text { Letter } B\end{array}$ & 0.01 \\
\hline Overall letter & \multicolumn{2}{|c|}{$\begin{array}{l}\text { See Appendix A for sample letters. } \\
\text { Note that overall } 92.0 \% \text { of men and } \\
98.7 \% \text { of women were able to read the } \\
\text { letter. }\end{array}$} & $\begin{array}{c}54 \% \text { of men prefer } \\
\text { Letter B overall }\end{array}$ & $\begin{array}{l}70 \% \text { of women } \\
\text { prefer } \\
\text { Letter B overall }\end{array}$ & $<0.01$ \\
\hline
\end{tabular}

women reported that a partner had attended ANC with them during their current pregnancy. This baseline level of male partner attendance is in line with numbers reported in a study from Malawi, though lower than what has been observed in several other Sub-Saharan African studies [17, 18]. Both men and women expressed high interest in the use of invitation letters for male involvement and perceived information about fatherhood, general health screening, and
HIV and STI screening as incentives for male involvement in ANC.

Like others, we found that work and financial considerations were barriers to male ANC attendance [9]. Weekend clinic hours, earlier morning hours, shorter clinic wait times, fast-tracking men attending ANC with their partners, and/or "Father's Days" could provide solutions [19, 20]. Care must however be taken that encouragement of male partner 
attendance does not result in healthcare providers rejecting or stigmatizing women who do not attend with partners as documented in Tanzania [21]. We also observed that men had little knowledge of what occurs at ANC visits, which may result in disinterest among men and has been reported in other studies as well $[12,19,22]$. Our data support the suggestion made by Koo et al. that inviting male partners and highlighting their importance at ANC may help to shift attitudes and generate a more welcoming environment for male partners [23]. Evidence from Malawi also suggests that structural changes to make ANC more male-friendly can result in greater male participation [17].

Our findings further suggest that men and women perceive health assessments for men as incentives for male ANC involvement. In our study, women were less inclined than men to emphasize HIV testing in the invitation letter. This may be because women were less comfortable with giving their partner a letter that invites them for HIV testing, or it may be that women perceive their partners as less likely to attend if the invitation letter specifically highlights HIV testing. A randomized control trial involving a letter invitation in Tanzania found decreased HIV testing among women attending ANC with their partners as compared to women randomized to receive individual testing, reinforcing that women's comfort with any male involvement intervention is essential [24].

Our study was specifically designed to access acceptability and preferences around male involvement. A study strength is that both men and women were included, with representation of both HIV positive and HIV negative participants. Inclusion of both sexes is critical as even if men are amenable to attending, male involvement is unlikely to occur if the woman does not want or invite him to participate in care. There were however some limitations to this analysis. While men were included, we did not specifically recruit men with currently pregnant partners and thus opinions of the participating men will not precisely reflect those of men whose partners are currently pregnant. We could not verify the accuracy of reports by men and women regarding prior male involvement. Furthermore, given that women were at varying gestational ages during enrolment, the number of women with male partner attendance during the current pregnancy may be underestimated as she was not yet at her final ANC visit. Results from the study are from a single clinic and thus may not be generalizable to the population more broadly. Finally, enrolling men at a clinic may result in a biased response, as these men may be more likely to engage in positive health seeking behaviour.

\section{Conclusions}

Increasing male involvement in PMTCT programming has been shown to improve health outcomes for the mother and child $[6,25]$. Male participation in ANC is highly acceptable to both men and women but rarely practiced. Interventions should make ANC male-friendly, emphasize development of parenting skills, raise the perception that ANC is not a woman's activity but is about promoting family health, and provide comprehensive incentives for male partner attendance, including integrated health services for men. This may motivate women to invite men, as well as encourage men's attendance. Future studies should assess the impact of such interventions on male involvement as well as maternal retention and treatment adherence within PMTCT to determine their true value.

\section{Disclosure}

The content is solely the responsibility of the authors and does not necessarily represent the official views of USAID or the National Institutes of Health.

\section{Competing Interests}

The authors have no competing interests to report.

\section{Authors' Contributions}

Sheree R. Schwartz, Annelies Van Rie, and Jean Bassett conceived the study; the study was implemented by Nompumelelo Yende, Sheree R. Schwartz, Jean Bassett, and Nora S. West. Data analysis was done by Sheree R. Schwartz. Writing, interpretation of results, and intellectual contribution to the paper were led by Nompumelelo Yende, though all authors contributed. All authors have read and approved the text as submitted.

\section{Acknowledgments}

The authors are grateful to the Witkoppen Health and Welfare Centre team and patients for their time and for making this study possible. The support of Thembisile Makhomboti and all of the staff at the antenatal clinic was essential to this research. This study was funded by the United States Agency for International Development (USAID) under Award no. AID-674-1200033. Sheree Schwartz received support for this work from the UJMT Fogarty Grant, supported by the Fogarty International Center of the National Institutes of Health under Award no. R25TW009340.

\section{References}

[1] K. Clouse, A. Pettifor, K. Shearer et al., "Loss to follow-up before and after delivery among women testing HIV positive during pregnancy in Johannesburg, South Africa," Tropical Medicine \& International Health, vol. 18, no. 4, pp. 451-460, 2013.

[2] A. E. Goga, T.-H. Dinh, D. J. Jackson et al., "First populationlevel effectiveness evaluation of a national programme to prevent HIV transmission from mother to child, South Africa," Journal of Epidemiology and Community Health, vol. 69, no. 3, pp. 240-248, 2015.

[3] I. Hodgson, M. L. Plummer, S. N. Konopka et al., "A systematic review of individual and contextual factors affecting ART initiation, adherence, and retention for HIV-infected pregnant and postpartum women," PLoS ONE, vol. 9, no. 11, Article ID e111421, 2014.

[4] T. Phillips, E. Thebus, L.-G. Bekker, J. Mcintyre, E. J. Abrams, and L. Myer, "Disengagement of HIV-positive pregnant and postpartum women from antiretroviral therapy services: a 
cohort study," Journal of the International AIDS Society, vol. 17, Article ID 19242, 2014.

[5] L. Tenthani, A. D. Haas, H. Tweya et al., "Retention in care under universal antiretroviral therapy for HIV-infected pregnant and breastfeeding women (“Option B+") in Malawi," AIDS, vol. 28, no. 4, pp. 589-598, 2014.

[6] A. Aluisio, B. A. Richardson, R. Bosire, G. John-Stewart, D. Mbori-Ngacha, and C. Farquhar, "Male antenatal attendance and HIV testing are associated with decreased infant HIV infection and increased HIV-free survival," Journal of Acquired Immune Deficiency Syndromes, vol. 56, no. 1, pp. 76-82, 2011.

[7] J. Dunlap, N. Foderingham, S. Bussell, C. W. Wester, C. M. Audet, and M. H. Aliyu, "Male involvement for the prevention of mother-to-child HIV transmission: a brief review of initiatives in East, West, and Central Africa," Current HIV/AIDS Reports, vol. 11, no. 2, pp. 109-118, 2014.

[8] C. Farquhar, J. N. Kiarie, B. A. Richardson et al., "Antenatal couple counseling increases uptake of interventions to prevent HIV-1 transmission," Journal of Acquired Immune Deficiency Syndromes, vol. 37, no. 5, pp. 1620-1626, 2004.

[9] J. Ditekemena, O. Koole, C. Engmann et al., "Determinants of male involvement in maternal and child health services in subSaharan Africa: a review," Reproductive Health, vol. 9, article 32, 2012.

[10] F. Morfaw, L. Mbuagbaw, L. Thabane et al., "Male involvement in prevention programs of mother to child transmission of HIV: a systematic review to identify barriers and facilitators," Systematic Reviews, vol. 2, article no. 5, 2013.

[11] L. I. Kululanga, J. Sundby, A. Malata, and E. Chirwa, "Striving to promote male involvement in maternal health care in rural and urban settings in Malawi-a qualitative study," Reproductive Health, vol. 8, no. 1, article 36, 2011.

[12] G. N. Nkuoh, D. J. Meyer, P. M. Tih, and J. Nkfusai, "Barriers to men's participation in antenatal and prevention of mother-tochild HIV transmission care in Cameroon, Africa," Journal of Midwifery \& Women's Health, vol. 55, no. 4, pp. 363-369, 2010.

[13] A. Adelekan, P. Omoregie, and E. Edoni, "Male involvement in family planning: challenges and way forward," International Journal of Population Research, vol. 2014, Article ID 416457, 9 pages, 2014.

[14] B. C. Mullany, "Barriers to and attitudes towards promoting husbands' involvement in maternal health in Katmandu, Nepal," Social Science and Medicine, vol. 62, no. 11, pp. 2798-2809, 2006.

[15] S. Brusamento, E. Ghanotakis, L. Tudor Car, M. H. vanVelthoven, A. Majeed, and J. Car, "Male involvement for increasing the effectiveness of prevention of mother-to-child HIV transmission (PMTCT) programmes," Cochrane Database of Systematic Reviews, vol. 10, Article ID CD009468, 2012.

[16] G. N. Nkuoh, D. J. Meyer, and E. M. Nshom, "Women's Attitudes Toward Their Partners' Involvement in Antenatal Care and Prevention of Mother-to-Child Transmission of HIV in Cameroon, Africa," Journal of Midwifery \& Women's Health, vol. 58, no. 1, pp. 83-91, 2013.

[17] S. M. Mphonda, N. E. Rosenberg, E. Kamanga et al., "Assessment of peer-based and structural strategies for increasing male participation in an antenatal setting in Lilongwe, Malawi," African journal of reproductive health, vol. 18, no. 2, pp. 97-104, 2014.

[18] L. Jennings, M. Na, M. Cherewick, M. Hindin, B. Mullany, and S. Ahmed, "Women's empowerment and male involvement in antenatal care: analyses of Demographic and Health Surveys
(DHS) in selected African countries," BMC Pregnancy and Childbirth, vol. 14, article 297, 2014.

[19] A. L. Nyondo, A. F. Chimwaza, and A. S. Muula, "Exploring the relevance of male involvement in the prevention of mother to child transmission of HIV services in Blantyre, Malawi," BMC International Health and Human Rights, vol. 14, article no. 30, 2014.

[20] R. Byamugisha, J. K. Tumwine, N. Semiyaga, and T. Tylleskär, "Determinants of male involvement in the prevention of mother-to-child transmission of HIV programme in Eastern Uganda: a cross-sectional survey," Reproductive Health, vol. 7, no. 1, article 12, 2010.

[21] S. W. Beckham, C. R. Shembilu, H. Brahmbhatt, P. J. Winch, C. Beyrer, and D. L. Kerrigan, "Female sex workers' Experiences with intended pregnancy and antenatal care services in Southern Tanzania," Studies in Family Planning, vol. 46, no. 1, pp. 5571, 2015.

[22] S. Theuring, P. Mbezi, H. Luvanda, B. Jordan-Harder, A. Kunz, and G. Harms, "Male involvement in PMTCT services in Mbeya Region, Tanzania," AIDS and Behavior, vol. 13, supplement 1, pp. S92-S102, 2009.

[23] K. Koo, J. D. Makin, and B. W. C. Forsyth, "Where are the men? Targeting male partners in preventing mother-to-child HIV transmission," AIDS Care, vol. 25, no. 1, pp. 43-48, 2013.

[24] S. Becker, R. Mlay, H. M. Schwandt, and E. Lyamuya, "Comparing couples' and individual voluntary counseling and testing for HIV at antenatal clinics in Tanzania: a randomized trial," AIDS and Behavior, vol. 14, no. 3, pp. 558-566, 2010.

[25] J. Yargawa and J. Leonardi-Bee, "Male involvement and maternal health outcomes: systematic review and meta-analysis," Journal of Epidemiology and Community Health, vol. 69, no. 6, pp. 604-612, 2015. 


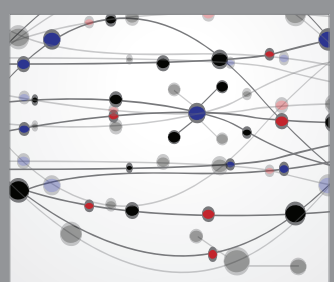

The Scientific World Journal
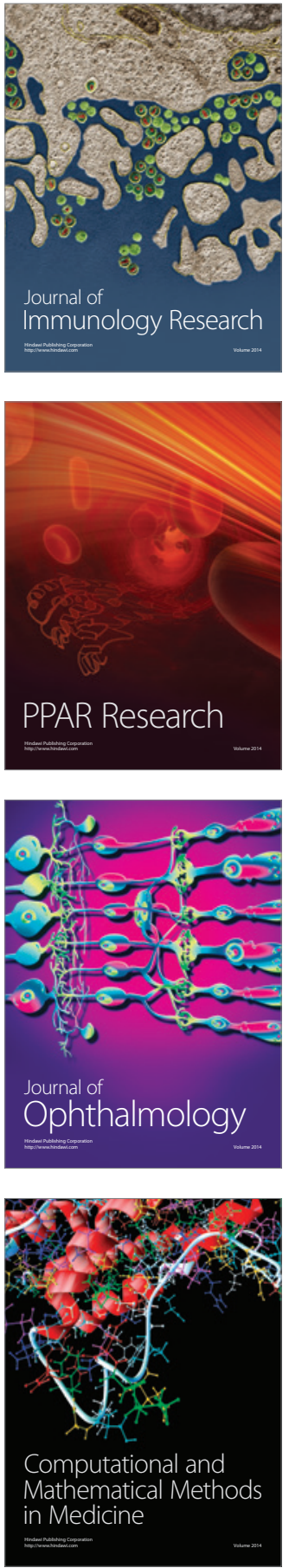

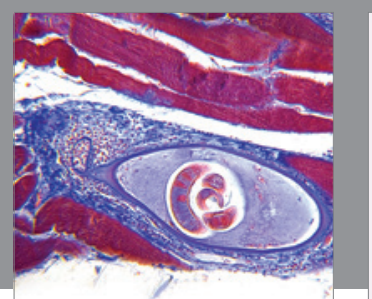

Gastroenterology Research and Practice
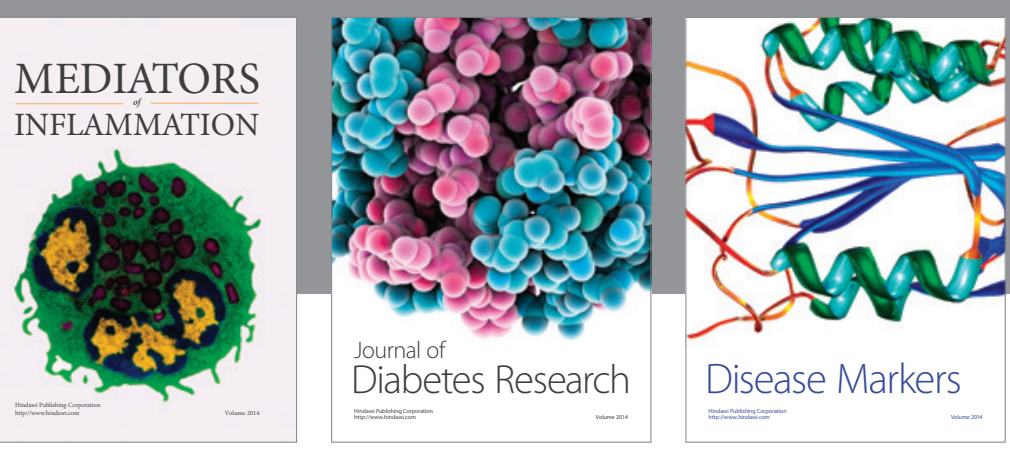

Disease Markers

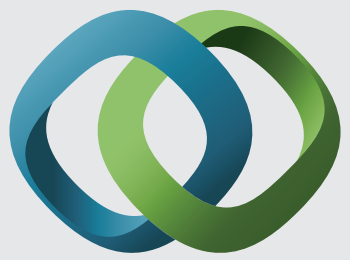

\section{Hindawi}

Submit your manuscripts at

https://www.hindawi.com
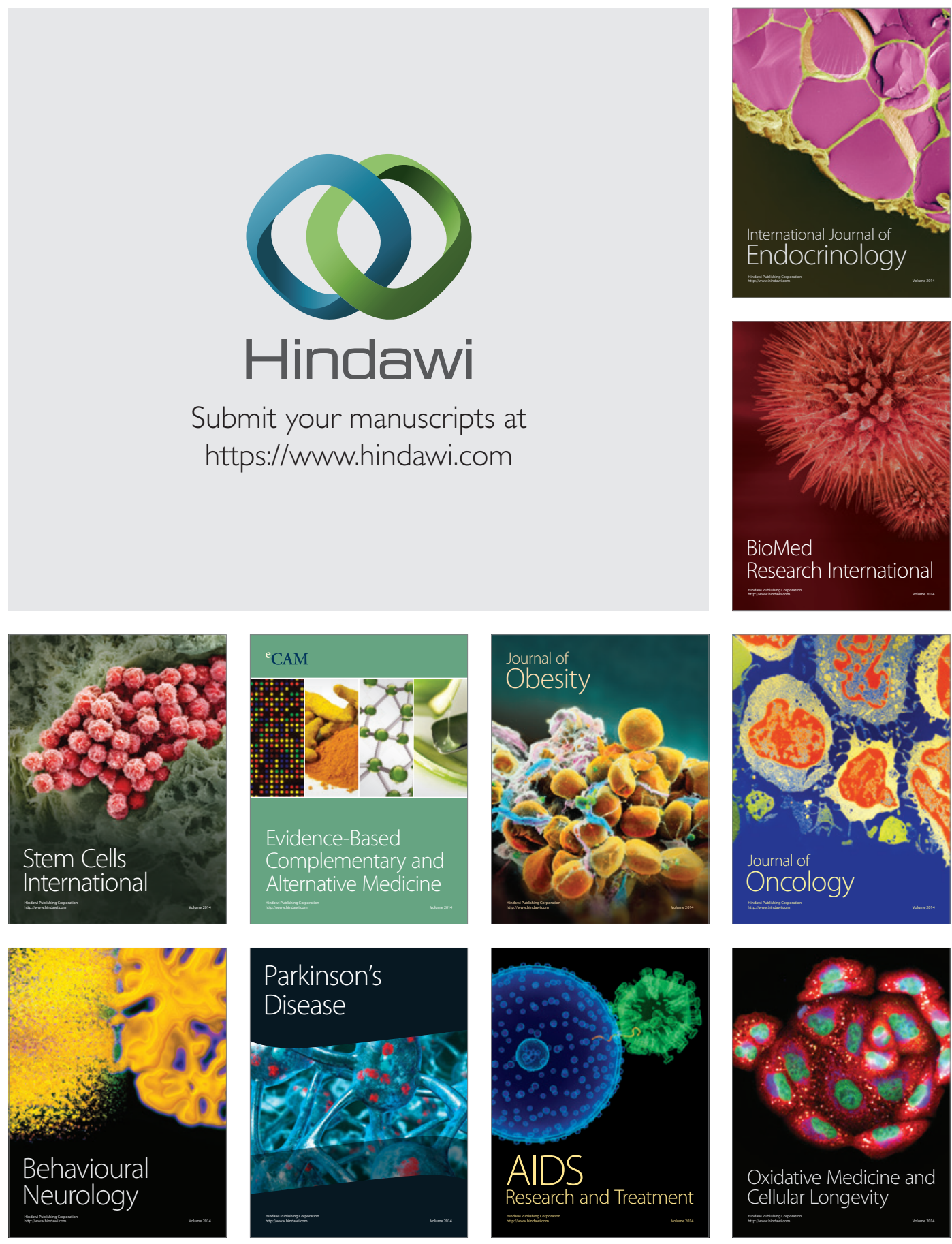